\title{
Control of Potato Bacterial Soft Rot Disease Caused by Erwinia carotovora subsp. carotovora with Streptomyces sioyaensis and Cinnamon Oil.
}

\author{
F. A. Mansour, A. H. Mohamedin ${ }^{*}$, A. E. Esmaeel ${ }^{1}$ and \\ Huda H. Badr ${ }^{1}$ \\ Botany Department, Faculty of Science, Mansoura, University, \\ Mansoura and ${ }^{1}$ Agricultural Research Center, Cairo, Egypt.
}

\begin{abstract}
OFT rot of potato is one of the most important diseases caused by D Erwinia carotovora subsp. carotovora. Possibilities of its biological control were investigated by the use of some actinomycetes antagonists for controlling E. carotovora subsp. carotovora. A total of 40 different actinomycetes strains were isolated from the rhizosphere soil of healthy potato plants collected from different localities of Dakahlyia Province, Egypt. These were then tested, in vitro, for their antibacterial activity against $E$. carotovora subsp. carotovora using an agar disc method. Eight isolates were active against E. carotovora subsp. carotovora and the most active isolate was selected for further tests and characterized by conventional methods. Morphological, physiological and cultural characterization of the most active isolate established that it was closely related to Streptomyces sioyaensis.
\end{abstract}

On the other hand, 28 commercial plant essential oils were screened, in vitro, to evaluate their inhibitory activities against $E$. carotovora subsp. carotovora. Nine out of 28 oils exhibited considerable inhibitory activities and the oil of Cinnamomum zeylanicum (cinnamon oil) was the most active.

Controlled bacterial soft rot of potatoes were carried out with $S$. sioyaensis and cinnamon oil in greenhouse experiments. Treatment of potato tubers with $S$. sioyaensis or cinnamon oil either individually or in combination, caused significant decrease in the percentage of soft rot disease at harvest time and after storage compared with control treatment. Different formula of $S$. sioyaensis (powder, suspension and granules) showed different effects on reducing disease incidence. Powder formulation of $S$. sioyaensis showed the highest reduction in disease incidence at harvest time and after storage. Increasing dose of $S$. sioyaensis in granules formula enhanced its efficacy in reducing disease incidence of potato tubers.

Keywords: Potato, Soft rot, Biological control, S. sioyaensis, Cinnamon oil, E. carotovora subsp. carotovora.

Potato (Solanum tuberosum L.) is affected by five bacterial diseases namely: bacterial wilt or brown rot caused by Ralstonia solanacerum, soft rot of tubers

* Corresponding author: e-mail: amohamedin@mans.edu.eg 
and stem caused by E. carotovora subsp. carotovora and E. carotovora subsp. atroseptica, ring spot caused by Clavibacter michiganense subsp. sepedonicus and common scab caused by Streptomyces scabies.

In Egypt, ring rot does not occur and the common scab is a minor disease. However, bacterial wilt and soft rot diseases are the most destructive and wide spread in tropics, subtropics and warm temperate regions (Bradbury, 1977).

Bacterial soft rot is considered one of the most important potato diseases causes losses in the field and one of the few diseases that can spread extensively in stores (Lund, 1979) and also cause significant losses during storage period (Helias et al., 2000). Protection of potato plants from the aforementioned diseases using chemicals has been attempted with limited success.

Biological control has been found of immense potential in management of soft rot of potatoes. The basic idea of biological control is a reduced infection caused by rhizosphere colonizers antagonizing E. carotovora subsp. carotovora and E. carotovora subsp. atroseptica at the root infection site. Certain bacteria like Pseudomonas fluorescens, Pseudomonas putida and Bacillus sp. have been found to delay the development and reduce incidence of soft rot of potatoes (Tawfik et al., 2001). In this respect, Sharga \& Lyon (1998) reported that Bacillus subtilis (Bs 107) had complete activity in vivo against E. carotovora subsp. carotovora and E. carotovora subsp. atroseptica.

Kastelein et al. (1999) found that some strains of Pseudomonas fluorescens and Pseudomonas putida reduced the development of black leg disease. Also similar results have been recorded by Lucon \& Melo (1999), Roberti \& Selmi (1999) and Aysan et al. (2003). In addition, several isolates of non-pathogenic Streptomyces sp. have been shown to significantly reduce the severity of potato scab caused by Streptomyces scabies (Liu et al., 1995 and Ryan et al., 2004).

The most recent information that relates to some plant extracts or their active constituents are widely used as antimicrobial agents in controlling plant diseases. The use of plant extracts or purified known chemicals is a new approach that showed promising results in reducing certain plant diseases with less environmental pollution (Zedan, 1993 and Badr, 2006).

In this respect, Deans \& Sviboda (1990) reported that volatile oils of Origanum majorana has inhibitory effect on the growth of $E$. carotovora. Barnejee \& Nigam (1978) measured the antimicrobial activity of Curcuma longa essential oil against E. carotovora and Pseudomonas solanacearam. Similar results have been obtained by Ibrahim et al. (1987), Atilla (1989) and Singh et al. (1992).

This work was undertaken to evaluate the efficacy of suppressive bacteria belonging to actinomycetes as biocontrol agents and some commercial essential oils to control soft rot disease of potatoes.

Egypt. J. Microbiol. 43 (2008) 


\title{
Material and Methods
}

\author{
Bacterial culture \\ E. carotovora subsp. carotovora that has been isolated from infected potato \\ tubers and completely identified using Bergey`s Manual of Systematic \\ Bacteriology (Lelliott \& Dickey, 1984). Isolation and identification were \\ performed according to Badr (2006). Pure cultures were maintained on nutrient \\ agar slants and subcultured every month.
}

\section{Pathogenicity test of the bacterial isolates}

Pathogenicity tests of the bacterial isolates on potato tubers (Sponta cultivar) were carried out according to Tolba (1998). The bacteria were incubated in nutrient agar at $28^{\circ} \mathrm{C}$ for $48 \mathrm{hr}$, washed and resuspended in sterile water. The growth of the bacterial suspension was approximately at $10^{8}$ c.f.u./ml $\left(\mathrm{OD}_{600}\right.$ of 0.05 ) and further on diluted in sterile water to reach $10^{6}$ c.f.u. $/ \mathrm{ml}$. Healthy potato tubers were surface sterilized by washing with soap, rinsed in sterile water for 15 min, immersed in $95 \%$ ethyl alcohol and instantly subjected to flam. In each tuber, a hole of $2 \mathrm{~cm}$ depth was made with a sterilized cork borer $(5 \mathrm{~mm}$ in diameter) and the tuber was inoculated with $0.5 \mathrm{ml}$ bacterial suspension $\left(10^{6}\right.$ cells $\left./ \mathrm{ml}\right)$. The hole of the tuber was closed with the removed potato cylinder, and then sealed with sterile vaspar. Inoculated tubers were kept in a moist condition at $28^{\circ} \mathrm{C}$ and examined for soft rot symptoms after 4 days. Control tubers were inoculated with sterilized distilled water. At least three tubers were used as replicates for each isolates.

\section{Isolation of antagonistic actinomycetes}

Actinomycetes were isolated from soil samples collected from the rhizosphere of healthy potato plants of different localities of Dakahlyia Governorate during 2004. Isolation was performed by serial dilution plate technique, according to Johnson et al. (1960), using starch-nitrate agar complemented with nystatin $(50 \mu \mathrm{g} / \mathrm{ml})$ as antifungal agent. The plates were incubated at $28^{\circ} \mathrm{C}$ for 7 to 14 days and differently looking colonies were picked up. Selected colonies of actinomycetes were transferred from mixed culture of the plates onto respective agar plates and incubated at $28^{\circ} \mathrm{C}$ for 7 days. A single colony of each pure culture was transferred to starch nitrate agar slant for maintenance till further examinations.

\section{In vitro antibacterial activities of actinomycetes}

Determination of antibacterial activities of pure actinomycetes cultures against the soft rot causing bacteria, E. carotovora subsp. carotovora, were performed using the agar disc method. Starch-nitrate agar plates were prepared and inoculated with actinomycetes cultures and incubated at $28^{\circ} \mathrm{C}$ for 7 days. A disc of $5 \mathrm{~mm}$ diameter was cut from each actinomycetes culture, using a sterilized cork borer and placed in the center of nutrient agar plates seeded with E. carotovora subsp. carotovora. All plates were incubated at $28^{\circ} \mathrm{C}$ for $24 \mathrm{hr}$. The antibacterial activities were measured by determination of the diameters of the inhibition zones. 
The antibacterial activity of the most active actinomycete isolate was further tested using the agar diffusion method according to Deans \& Ritchie (1987). Actinomycetes isolate was grown on starch-nitrate liquid media on a rotatory shaker incubator at $200 \mathrm{rpm}$ for 7 days at $28^{\circ} \mathrm{C}$. The culture filtrate was sterilized through a bacteria filter and tested for its antibacterial activity as follow; $1 \mathrm{ml}$ amount $\left(10^{6}\right.$ cells $\left./ \mathrm{ml}\right)$ of E. carotovora subsp. carotovora was pipetted into separate sterile Petri dishes to which $20 \mathrm{ml}$ amounts of molten nutrient agar $\left(45^{\circ} \mathrm{C}\right)$ were added. Once set, wells of $5 \mathrm{~mm}$ diameter were made in the center of each agar plate using sterilized cork borer, into which $100 \mu \mathrm{l}$ sterilized culture filtrate was added. The plates were then left undisturbed to allow diffusion of the sample into the agar and then incubated at $28^{\circ} \mathrm{C}$ for $24 \mathrm{hr}$. Following this, zones of growth inhibition were measured.

Pathogenicity test of the most active actinomycete isolate

The selected actinomycete was examined for its pathogenicity to be sure that it does not cause any disease for potato. Pathogenicity test was carried out as previously mentioned with the use of spore suspension of actinomycete instead of bacterial suspension.

Taxonomic identification of the most active actinomycete isolate

The most active actinomycete isolate was identified according to Bergey`s Manual of Determinative Bacteriology (Buchanan \& Gibbons, 1974), Bergey`s Manual of Systematic Bacteriology (Locci, 1989) and the keys proposed by Shirling \& Gottlieb (1968), Kuster (1972) and of Nonomura (1974). The cultural, morphological and physiological characteristics of the isolate were studied using media and methods described by Shirling \& Gottlieb (1966). Micromorphology of the strain was examined microscopically using a light microscope (Carl Zeiss MC80- standard 20-DVEGS-Germany) and spores were observed by scanning electron microscopy (Jeol JSM LV 5500). Cell wall composition of the strain was analyzed by the method described by Becker et al. (1965) and modified by Staneck \& Roberts (1974).

In vitro antibacterial activity of essential oils

Volatile oils used in this study were obtained from Badawyia Company, Mansoura, Egypt. The antimicrobial activity of the volatile oils against $E$. carotovora subsp. carotovora were screened using an agar diffusion technique (Deans \& Ritchie, 1987) as previously described.

The minimum inhibitory concentration (MIC) of the most active oil was determined using the agar dilution method according to Hammer et al. (1999).

In vivo antibacterial activity of Streptomyces sioyaensis and cinnamon oil

Greenhouse experiment was conducted in the winter season of 2005 to control the development of soft rot disease caused by E. carotovora subsp. carotovora using different treatments of the most active actinomycetes and the most active essential oil.

Egypt. J. Microbiol. 43 (2008) 
The experiment was performed in $30-\mathrm{cm}$ diameter round plastic pots $(7 \mathrm{~kg}$ autoclaved soil per pot). Potato seeds of Sponta cultivar were treated with different treatments of the biocontrol agents and essential oil (see later) and planted in the pots. Potato seeds without any treatments were planted as control. Each pot was planted with a single potato seed and inoculated with bacterial suspension $\left(10^{6}\right.$ cells $\left./ \mathrm{ml}\right)$ of $24 \mathrm{hr}$ old $E$. carotovora subsp. carotovora. Five pots were used as replicates for each treatment. Pots were arranged in a completely randomized design. Potato remained in the soil for about 100 days, before harvesting, and during which, the suitable cultural practices were applied. At the harvest time, the parameters of total number of tubers, total weight of tubers, number of diseased tubers, percentage of diseased tubers (disease incidence), and efficacy percentage were determined.

The effect of different greenhouse treatments on the development of potato bacterial soft rot during storage were carried out by storing healthy potato tubers after harvest at $22-28^{\circ} \mathrm{C}$ for 45 days and the values of disease incidence and efficacy percentage were estimated.

\section{Preparation of the biocontrol agent (bioagent)}

The most active isolate of the antagonistic actinomycetes was prepared in three different formulae: powder, suspension and granules. To prepare these forms, the actinomycete was grown on starch-nitrate liquid media for 7 days at $28^{\circ} \mathrm{C}$. The powder form was prepared by mixing the actinomycete culture with talc powder at $1: 1(\mathrm{v} / \mathrm{w})$ and the mixture was left to dry out. The suspension formula was prepared by blending the actinomycete culture, using electric belender, for $3 \mathrm{~min}$. Granules were prepared by adding $3 \mathrm{gm}$ of sodium alginate to $100 \mathrm{ml}$ of starch-nitrate liquid media and then autoclaved. Then, $100 \mathrm{ml}$ of actinomycete culture, grown on starch-nitrate liquid media, were added. The mixture was dropped into $3 \mathrm{M} \mathrm{CaCl}_{2} 2 \mathrm{H}_{2} \mathrm{O}$ solution under aseptic conditions at $4^{\circ} \mathrm{C}$ to form granules. The alginate beads formed and entrapped actinomycetes propagules were allowed to stabilize for $1 \mathrm{hr}$ and dried under sterile air flow after washing with sterile distilled water.

The effect of different doses of the most active antagonistic actinomycetes on controlling soft rot was studied using granules formula in three different doses $(0.5,1.0$ and $2.0 \mathrm{gm}$ of the most active actinomycete per pot).

\section{Statistical analysis}

The Tukey test was used for statistical analysis of the data (Tukey, 1953).

\section{Results}

\section{Isolation and identification of potato soft rot causing bacteria}

Twenty three isolates of Erwinia sp. were obtained from infected potato tubers showing typical soft rot symptoms. Pathogenicity test was carried out and all bacterial isolates proved to be pathogenic to potato tubers. These isolates were then subjected to morphological, cultural and biochemical studies and identified according to the 
diagnostic keys of Fahy \& Persley (1983), Bergey`s Manual of Systematic Bacteriology (Lelliott \& Dickey, 1984) and Bradbury (1986). Bacterial isolates No. 3, 6, 8, 13 and 18 were identified as E. carotovora subsp. carotovora (Badr, 2006). Regardless of the virulence of the pathogens, isolate No. (18) was used through out this study.

Isolation and in vitro screening of antibacterial activities of antagonistic actinomycetes

Fourty actinomycetes isolates were obtained from the rhizosphere soil of healthy potato plants. The actinomycetes isolates were screened for their antibacterial activities against E. carotovora subsp. carotovora using the agar disc method. Eight isolates, out of 40, exhibited inhibitory effect against $E$. carotovora subsp. carotovora with variable activities and actinomycete isolate No.15 showed the most pronounced antibacterial activities (Table 1).

TABLE 1. The antagonistic capacity of the active isolates of the tested actinomycetes against $E$. carotovora subsp. carotovora as demonstrated by diameters of inhibition zones.

\begin{tabular}{|c|c|}
\hline Actinomycete isolate No. & Mean diameter of inhibition zones(mm)* \\
\hline 5 & 30 \\
\hline 7 & 20 \\
\hline 12 & 28 \\
\hline 15 & 32 \\
\hline 22 & 14 \\
\hline 26 & 14 \\
\hline 33 & 15 \\
\hline 38 & 12 \\
\hline
\end{tabular}

*The recorded value is the mean of 3 replicates.

The antibacterial activity of the cell free culture filtrate of the most active actinomycete isolate (No.15) was examined using the cup plate method and the results showed that the isolate exhibited a great antibacterial activity as indicated by measuring the diameter of inhibition zone developed $(33 \mathrm{~mm})$.

Pathogenicity test of the most active actinomycete isolate (Streptomyces sioyaensis)

Pathogenicity test of Streptomyces sioyaensis showed no infection of potato tubers.

Taxonomic identification of the most active actinomycete isolate (No.15)

The actinomycete isolate No.15 formed mycelia filaments and chains of several spores. The aerial spores were not motile and were not borne on verticillate sporophores. Sugar analysis of cells showed glucose to be the main sugar, while galactose, xylose and arabinose could not be detected. The major amino acids in the cell wall hydrolyzates were glycine and L-DAP acid. Chemical analysis indicated that the isolate has cell wall type I. Chemical analysis of the cells and cell walls and morphological characteristics indicate that the isolate belongs to the genus 
Streptomyces from the criteria in Bergey`s Manual of Determinative Bacteriology (Buchanan \& Gibbons, 1974).

The morphological, cultural, physiological and antagonistic properties of the isolate are summarized in Table 2. In general, aerial mycelium was gray to white. Sporophores were spiral (Fig. 1). The surface of conidia was smooth (Fig. 2).

TABLE 2. Morphological, cultural, physiological, and antagonistic properties of actinomycete isolate No. 15 .

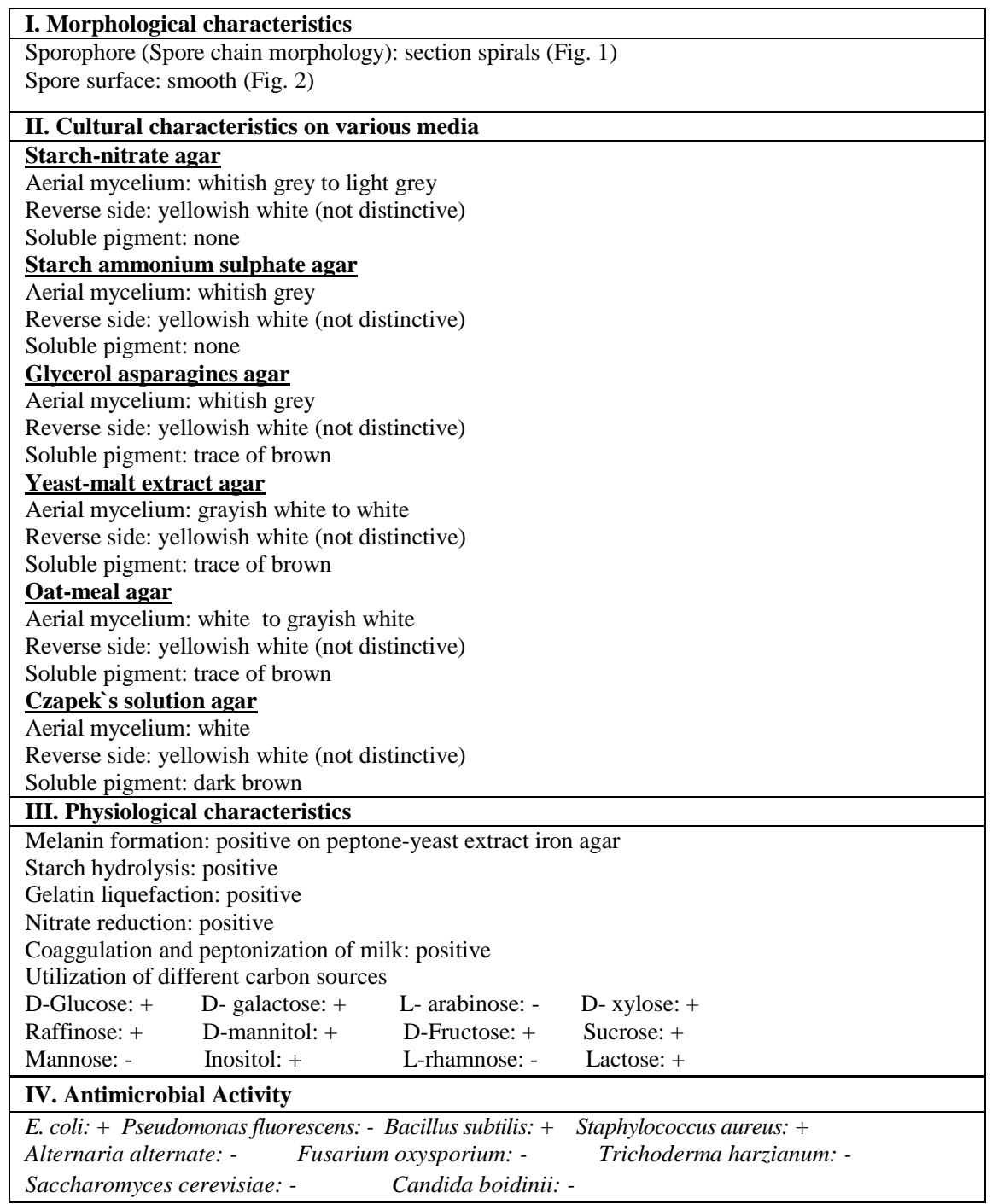


From the results presented in Fig. $1 \& 2$ and Table 2 and following the diagnostic keys of Bergey`s Manual (Buchanan \& Gibbons, 1974 and Locci, 1989) and surveying the literatures of the description of Streptomyces sp. in the articles of ISP (Shiriling \& Gottlieb, 1968), Kuster (1972) and Nonomura (1974), isolate No. 15 was identified as a strain belonging to Streptomyces sioyaensis (Nishimura et al., 1961).

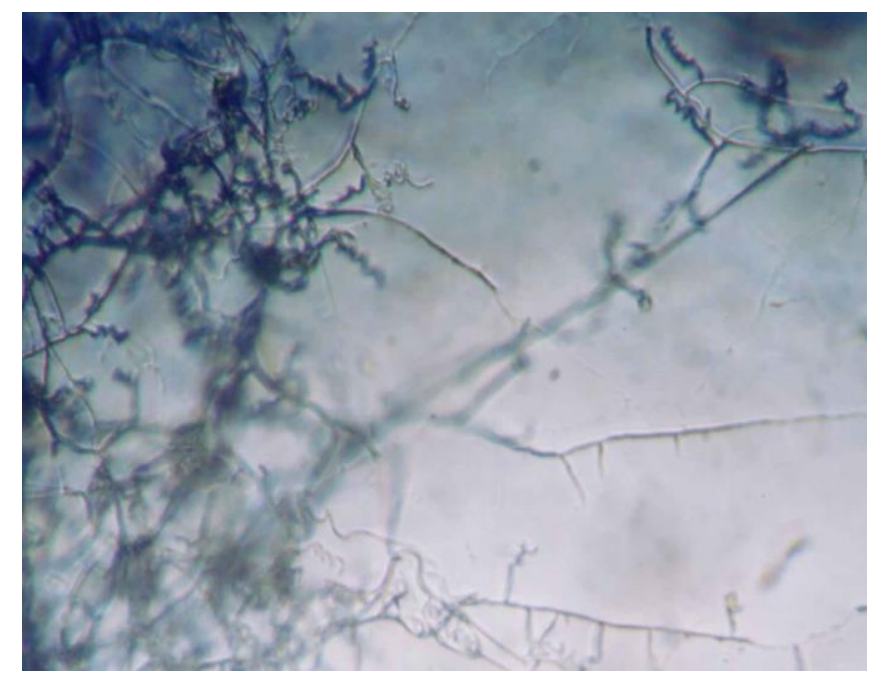

Fig. 1. Morphology of spore chain of isolate No. $15(x=1,000)$.

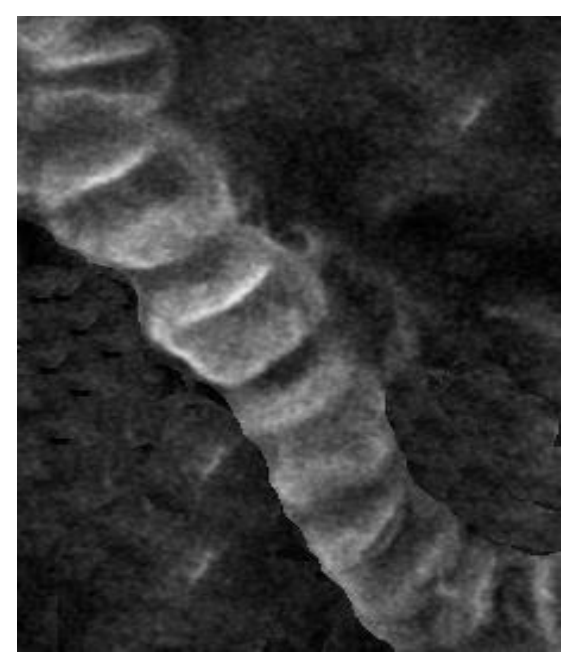

Fig. 2. Scanning electron micrograph of spore surface of isolate No. $15(x=15,000)$. 
In vitro antibacterial activities of essential oils

Twenty eight commercial plant essential oils were screened for their inhibitory activities aginst $E$. carotovora subsp. carotovora. The results obtained (Table 3) showed that only 9 oils exhibited inhibitory activities against $E$. carotovora subsp. carotovora with variable degrees as demonstrated by measuring the diameters of inhibition zones developed by the oils and the essential oil of Cinnamoum zeylincum (cinnamon oil) showed the greatest activity.

TABLE 3. The inhibitory activity of the tested essential oils against $E$. carotovora subsp. carotovora as demonstrated by diameters of inhibition zones.

\begin{tabular}{|l|c|l|c|}
\hline Commercial essential oil & $\begin{array}{c}\text { *Mean } \\
\text { diameter of } \\
\text { inhibition } \\
\text { zones(mm) }\end{array}$ & \multicolumn{1}{|c|}{$\begin{array}{c}\text { Commercial essential } \\
\text { oil }\end{array}$} & $\begin{array}{c}\text { *Mean } \\
\text { diameter of } \\
\text { inhibition } \\
\text { zones(mm) }\end{array}$ \\
\hline $\begin{array}{l}\text { Cinnamomum zeylanicum } \\
\text { Blume. }\end{array}$ & 35 & Raphanus sativus L. & 0 \\
\hline Mentha viridis L. & 26 & Allium cepa L. & 0 \\
\hline Syzgium aromaticum L. & 25 & Allium sativum L. & 0 \\
\hline Majorana hortensis L. & 22 & $\begin{array}{l}\text { Trigonella foenum } \text { - } \\
\text { graecum } \text { L. }\end{array}$ & 0 \\
\hline Petroselium sativum L. & 20 & Brassica nigra L. & 0 \\
\hline Cuminum cyminum L. & 20 & Jasminum grandiflorum L. & 0 \\
\hline Foeniculum vulgare Mill. & 20 & Anethum graveolens L. & 0 \\
\hline Citrus limon L. & 15 & Rosmarinus officinalis L. & 0 \\
\hline Lavandula officinalis L. & 14 & Ocimum bacilicum L. & 0 \\
\hline Thymus vulgaris L. & 0 & Capsicum frutescens L. & 0 \\
\hline Nigella sativa L. & 0 & Coriandrum sativum L. & 0 \\
\hline Eucalyptus rostrata Schlecht. & 0 & Pinus halepensis Mill. & 0 \\
\hline Eruca sativa Mill. & 0 & Daucus carota L. & 0 \\
\hline Carum carvi L. & 0 & Elettaria cardamomum & 0 \\
& Maton. & \\
\hline
\end{tabular}

*The recorded value is the mean of 3 replicates.

The minimum inhibitory concentration (MIC) of the cinnamon oil was determined using agar dilution method and it was found to be $0.5 \%(\mathrm{v} / \mathrm{v})$.

The antibacterial activity of cinnamon oil against Streptomyces sioyaensis was also tested using the cup plate method and no inhibition was detected.

In vivo antibacterial activities of Streptomyces sioyaensis and cinnamon oil

The greenhouse experiment was designed to evaluate the efficacy of different treatments of S. sioyaensis and cinnamon oil in controlling bacterial soft rot of potato. Disease incidence in addition to total number and total weight of 
tubers/treatment were used as parameters to detect the effect of different treatments in controlling soft rot of potato.

The results presented in Tables $4 \& 5$ indicate that all treatments were of marked potentiality for successful control of potato soft rot; they significantly reduced disease incidence and enhanced yield comparing with the control. Cinnamon oil, $S$. sioyaensis in powder formula and combination between cinnamon oil and S. sioyaensis (powder formula) strongly inhibited (100\%) soft rot caused by E. carotovora subsp. carotovora on potato tubers. S. sioyaensis (granule formula, 1.0g) and (granule formula, 2.0g) resulted in $92.31 \%$ and $96.30 \%$, reduction of the disease, respectively. S. sioyaensis (suspension formula) and $S$. sioyaensis (granule formula, $0.5 \mathrm{~g}$ ) prevented symptoms development at the lowest ratio, they were $88.47 \%$.

The results in Tables $4 \& 5$ also indicated that $S$. sioyaensis in different formulae had significant different effects on disease incidence. From this the formula with the highest effect on disease reduction was the powder formula $(100 \%)$, followed by granules $(96.3-88.47 \%)$, and suspension $(88.47 \%)$.

TABLE 4. Effect of different greenhouse treatments on controlling bacterial soft rot.

\begin{tabular}{|l|c|c|c|c|c|}
\hline Treatment & $\begin{array}{c}\text { Total } \\
\text { number of } \\
\text { tubers }\end{array}$ & $\begin{array}{c}\text { Total } \\
\text { weight of } \\
\text { tubers }(\mathbf{g})\end{array}$ & $\begin{array}{c}\text { Number of } \\
\text { diseased } \\
\text { tubers }\end{array}$ & $\begin{array}{c}\text { Disease } \\
\text { incidence } \\
(\%)\end{array}$ & $\begin{array}{c}\text { Efficacy } \\
(\%)\end{array}$ \\
\hline Cinnamon oil & 27 & 1134 & zero & zero & 100 \\
\hline S.sioyaensis (powder) & 27 & 1150 & zero & zero & 100 \\
\hline S.sioyaensis (suspension) & 26 & 930 & 3 & 11.53 & 88.47 \\
\hline S.sioyaensis (granules, 0.5 g) & 26 & 857 & 3 & 11.53 & 88.47 \\
\hline S.sioyaensis (granules, 0.1 g) & 26 & 996 & 2 & 7.69 & 92.31 \\
\hline S.sioyaensis (granules, $2.0 \mathrm{~g}$ ) & 27 & 1044 & 1 & 3.70 & 96.30 \\
\hline $\begin{array}{l}\text { Cinnamon oil }+ \text { S.sioyaensis } \\
\text { (powder) }\end{array}$ & 28 & 1210 & zero & zero & 100 \\
\hline Control & 27 & 910 & 9 & 33.33 & 66.67 \\
\hline
\end{tabular}

The results in Tables $4 \& 5$ further indicated that different doses of S.sioyaensis have different effects on disease incidence where increasing dose of S. sioyaensis increased its efficacy in controlling bacterial soft rot. From this, the dose with highest effect on disease development was $2 \mathrm{~g} /$ pot of $S$. sioyaensis granules $(96.30 \%)$, followed by $1 \mathrm{~g} /$ pot $(92.31 \%)$, and $0.5 \mathrm{~g} / \mathrm{pot}(88.47 \%)$.

This experiment was carried out to evaluate the effect of different treatments carried out during growing season on disease incidence during storage period. 
CONTROL OF POTATO BACTERIAL SOFT ROT ....

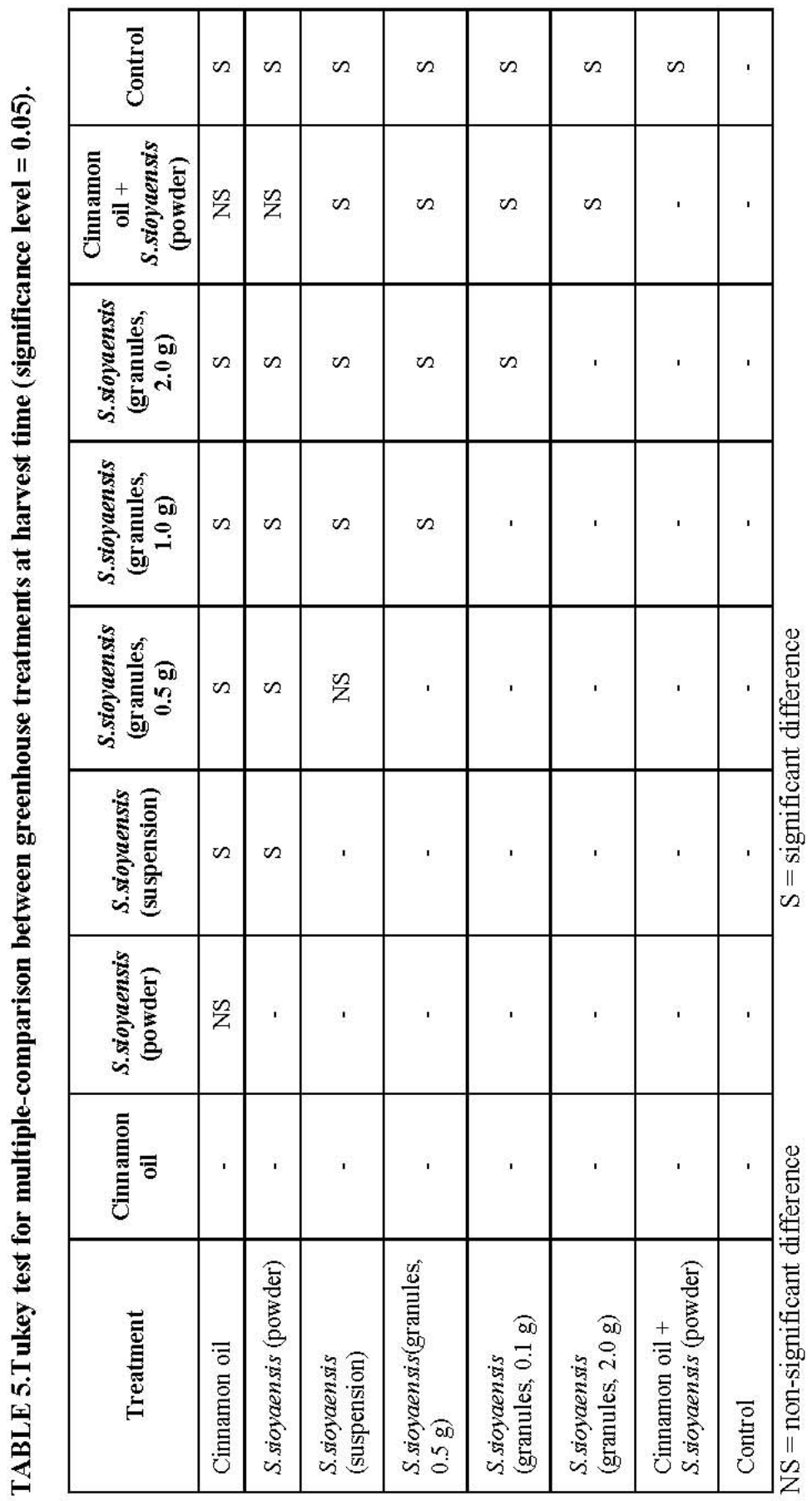

Egypt. J. Microbiol. 43 (2008) 
The results presented in Tables $6 \& 7$ show that all treatments significantly reduced disease development during storage comparing with the control. Combination between cinnamon oil and $S$. sioyaensis (powder formula) completely inhibited (100\%) soft rot disease. S. sioyaensis in powder formula and cinnamon oil had great effect in reducing disease development during storage $(95.66 \%)$. S. sioyaensis (granules, $2.0 \mathrm{~g}$ ) prevented disease development at $91.31 \%$ ratio while $S$. sioyaensis(granules, $1.0 \mathrm{~g}$ ) prevented disease development at $86.96 \%$ ratio. S. sioyaensis (suspension) and S. sioyaensis (granules, $0.5 \mathrm{~g}$ ) prevented symptoms development at the lowest ratio, they were $82.61 \%$.

TABLE 6. Effect of greenhouse treatments on disease development during storage.

\begin{tabular}{|l|c|c|c|c|}
\hline \multicolumn{1}{|c|}{ Treatment } & $\begin{array}{c}\text { Total } \\
\text { number of } \\
\text { tubers }\end{array}$ & $\begin{array}{c}\text { Number of } \\
\text { diseased } \\
\text { tubers }\end{array}$ & $\begin{array}{c}\text { Disease } \\
\text { incidence } \\
(\%)\end{array}$ & $\begin{array}{c}\text { Efficacy } \\
(\%)\end{array}$ \\
\hline Cinnamon oil & 23 & 1 & 4.34 & 95.66 \\
\hline S.sioyaensis (powder) & 23 & 1 & 4.34 & 95.66 \\
\hline S.sioyaensis (suspension) & 23 & 4 & 17.39 & 82.61 \\
\hline $\begin{array}{l}\text { S.sioyaensis } \text { (granules, } \\
\text { 0.5 g) }\end{array}$ & 23 & 4 & 17.39 & 82.61 \\
\hline $\begin{array}{l}\text { S.sioyaensis } \text { (granules, } \\
\text { 0.1 g) }\end{array}$ & 23 & 3 & 13.04 & 86.96 \\
\hline $\begin{array}{l}\text { S.sioyaensis } \text { (granules, } \\
\text { 2.0 g) }\end{array}$ & 23 & 2 & 8.69 & 91.31 \\
\hline $\begin{array}{l}\text { Cinnamon oil + } \\
\text { S.sioyaensis (powder) }\end{array}$ & 23 & Zero & Zero & 100 \\
\hline Control & 18 & 10 & 55.55 & 44.45 \\
\hline
\end{tabular}

Different formulae of $S$. sioyaensis had significant different effects on disease development during storage (Tables 6 \& 7). Powder formula showed the greatest effect in reducing disease incidence $(95.66 \%)$. Granules formula occupied the second rank in this respect $(91.31-82.61 \%)$. Finally, suspension formula had the least effect $(82.61 \%)$.

Different doses of S. sioyaensis had significant different effects on disease development during storage, where increasing dose of $S$. sioyaensis resulted in reducing disease development during storage (Tables $6 \& 7$ ). $2 \mathrm{~g} / \mathrm{pot}$ of $S$. sioyaensis granules resulted in $91.31 \%$ reduction of the disease while $1.0 \mathrm{~g} / \mathrm{pot}$ of $S$. sioyaensis granules resulted in $86.96 \%$ disease reduction. $0.5 \mathrm{~g} / \mathrm{pot}$ of $S$. sioyaensis granules prevented disease development at the lowest ratio $(82.61 \%)$.

\section{Discussion}

A major limiting factor in profitable potato production is disease, which can be seed-borne, soil-borne, or both. Soft rot, caused by the bacteria E. carotovora subsp. carotovora, is the most serious of all storage diseases. This organism spreads rapidly from tuber to tuber if the conditions are appropriate.

Egypt. J. Microbiol. 43 (2008) 
CONTROL OF POTATO BACTERIAL SOFT ROT ....

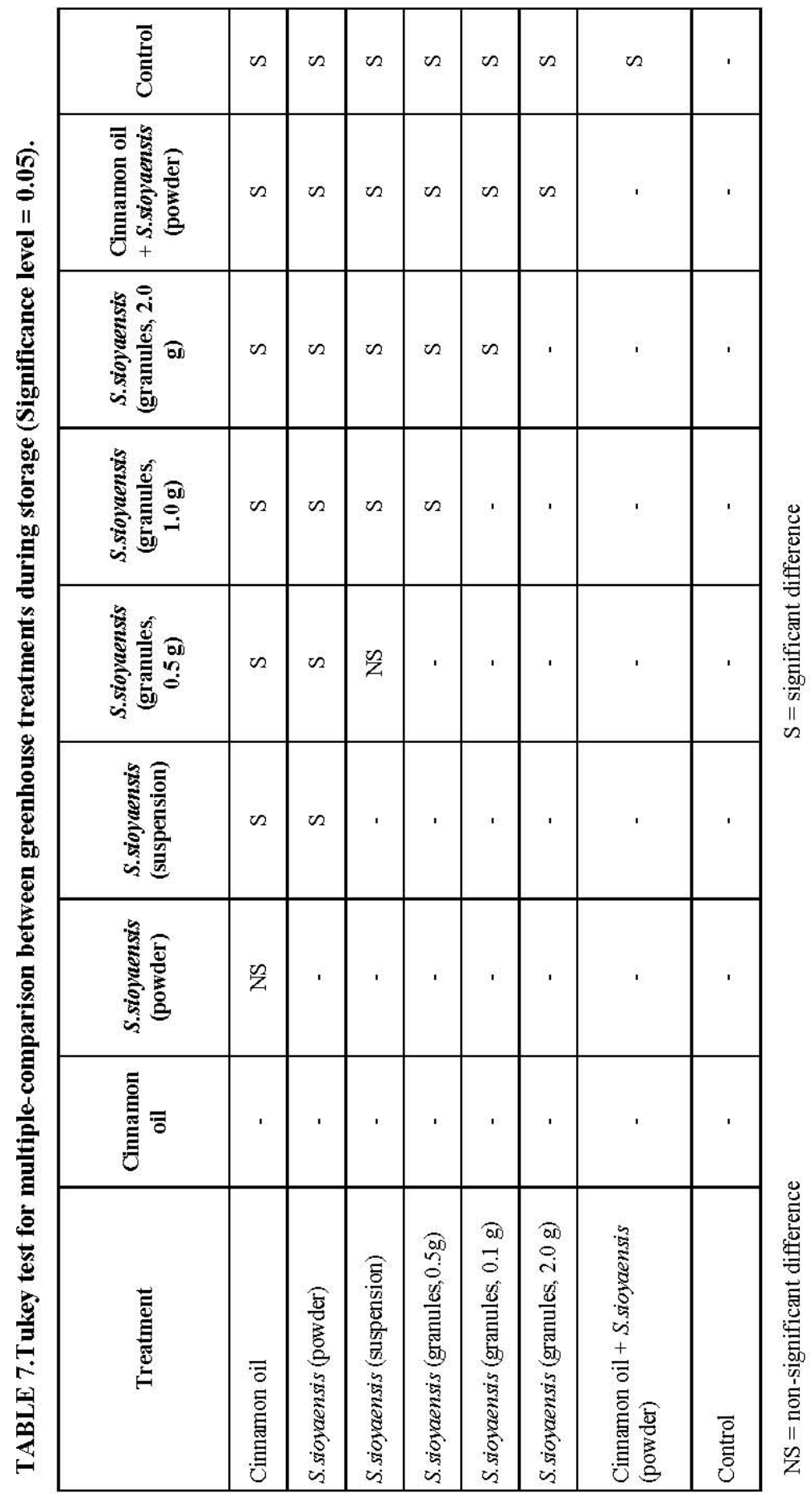

Egypt. J. Microbiol. 43 (2008) 
Among soil microorganisms, bacteria and fungi and to a lesser extent actinomycetes, have received considerable attention as biocontrol agents of soil borne plant pathogens. Several researchers have successfully employed antagonistic bacteria, Streptomyces and yeasts to control plant bacterial diseases (Alivizatos \& Pantazis, 1992; Aysan et al., 2003 and Ryan et al., 2004). One of the alternative control methods of E. carotovora subsp. carotovora is the use of biocontrol agents. In this study, actinomycetes were developed as potential biocontrol agent for controlling soft rot caused by $E$. carotovora subsp. carotovora on potato in greenhouse conditions.

In this investigation, 40 isolates of actinomycetes were screened in the laboratory for their antagonistic capacity against $E$. carotovora subsp. carotovora. Eight isolates exhibited antagonistic activity against E. carotovora subsp. carotovora. The most active isolate, identified as Streptomyces sioyaensis, was tested under greenhouse conditions to control potato soft rot where it showed great reduction in disease incidence at harvest time and after storage.

Streptomyces spp. have been employed by Hayashida et al. (1988), Tu (1988) and Liu et al. (1995) as a biocontrol measure against many diseases and it was stated that, many strains of Streptomyces spp. produce antibacterial metabolites or antibiotics which are active against several plant pathogens.

Our results suggest that $S$. sioyaensis, a beneficial antagonist, can significantly reduce soft rot disease caused by E. carotovora subsp. carotovora on potato in greenhouse experiment and may be a useful bioagent for the disease management in Egypt.

Suitable formulation of the bacterium for its efficiency should also be investigated, in order that this beneficial bacterium may be presented to farmers for commercial usage in the future.

In our greenhouse experiment, the antagonistic S. sioyaensis was used in different formulae to determine the correlation between different formulae of the antagonist and its efficacy in controlling the bacterial soft rot of potato. Data obtained revealed that using the antagonist as suspension showed poor effect comparing with using the antagonist as powder or granules. This is due to that either granules or powder contain organic matter supplemented with necessary nutrient substances which improve growth of the antagonist, also act as suitable food base of the antagonist. This food base leads to well establishment of the antagonist in the infection court, causing reduction in the pathogenic propagules and consequently reduce the contamination of the produced tubers with the pathogenic bacteria. This reduction in inoculum of pathogenic bacteria translated to reduction in disease incidence under store condition (Abd El-Moity et al., 1991). These results are in agreement with those obtained by Phae et al. (1992), Kay \& Stewart (1994) and Tolba (1998).

Egypt. J. Microbiol. 43 (2008) 
On the other hand, powder or granules contain some nutrient substances which stimulate inhibitors production by the antagonist. These inhibitors play an important role on stability of the formula and also improve establishment of antagonist (Bull et al., 1991).

Effect of different doses of the antagonistic S. sioyaensis on disease incidence was also studied. Data obtained showed a positive correlation between dose and reduction in disease incidence at harvest time and after storage. This is due to that increasing inoculum leads to increasing the efficacy of the antagonist which consequently reduce the inoculum of pathogenic bacteria. These results are in agreement with those of Kloepper (1983), Abd El-Moity et al. (1991) and Tolba (1998).

The antimicrobial properties of plant volatile oils from a wide variety of plants have been reported in numerous investigations (Hammer et al., 1999; Imai et al., 2001 and Guynot et al., 2003).

In this investigation, twenty eight commercial plant essential oils were screened for their inhibitory activities against E. carotovora subsp. carotovora. Nine essential oils exhibited antibacterial activities and the cinnamon oil had the greatest activity. The great antibacterial activity of cinnamon oil showed in this investigation is in agreement with many other investigations (Boyd \& Gouk, 1997 and Baratta et al., 1998).

Treatment of potato tubers with cinnamon oil prior to sowing showed great reduction in disease incidence at harvest time $(0 \%)$ or after storage $(4.34 \%)$.

Combination between $S$. sioyaensis in powder formula and cinnamon oil resulted in complete reduction (disease incidence $0 \%$ ) of soft rot of potato tubers at harvest time and after storage.

In conclusion, the results of this study confirmed the possibility of using $S$. sioyaensis or cinnamon oil in controlling bacterial soft rot of potato. It is more useful to use them in combination.

\section{References}

Abd El-Moity, T. H., El-Deeb, A. A. and Radwan, I. A. (1991) Biological control of seedling disease and pod rot of peanut, under greenhouse and field conditions. Egypt J. Appl. Sci. 6 (1), 103.

Alivizatos, A. S. and Pantazis, S. (1992) Preliminary studies on biological control of potato common scab caused by Streptomyces sp. In: "Biological Control of Plant Diseases Progress and Challenges for the Future", Tjamos, E.C., Papavizas, G.C.,Cook, R. J. (Ed.), Vol. 230, pp. 85-93, NATO ASI Series, Kluwer Academic Publishers, Dordrecht. 
Atilla, A. (1989) Antimicrobial activity of black cumin (Nigella sativa L.). Dept. Food Sci., Fac. Agric., Ataturk Univ. 6 (1), 63.

Aysan, Y., Karatas, A. and Cinar, O. (2003) Biological control of bacterial stem rot caused by Erwinia chrysanthemi on tomato. Crop Protection, 22, 807-811.

Badr, H. H. E. (2006) Integrated control of potato soft rot in Dakahlyia Governorate. M.Sc. Thesis, Botany Department, Faculty of Science, Mansoura University, Mansoura, Egypt.

Baratta, M.T., Dorman, H.J.D., Deans, S.G., Figueiredo, A.C., Barroso, J.G. and Ruberto, G. (1998) Antimicrobial and antioxidant properties of some commercial essential oils. Flav. Fragr. J. 13(4),235-244.

Barnejee, A. and Nigam, S. S. (1978) Antimicrobial efficacy of the essential oil of Curcuma longa. Indian J. Med. Res. 68, 864-866.

Becker, B., Lechevalier, M. P. and Lechevalier, H. A.(1965) Chemical composition of cell wall preparations from strains of various form-genera of aerobic actinomycetes. Appl. Microbiol. 13, 236-243.

Boyd, R. J. and Gouk, S. C. (1997) Inhibitory activities of essential oils against plant pathogenic bacteria, Hort. Research, Ruakura Research Center, Private Bag 3123, Hamilton.

Bradbury, J. F. (1986) "Guide to Plant Pathogenic Bacteria", pp.61-73, C.A.B. International, UK.

Bradbury, J. F. (1977) CMI Distribution Maps of Plant Disease No. 138(5 ${ }^{\text {th }}$ ed.) CAB International, Oxford (GB).

Buchanan, R. E. and Gibbons, N. E. (1974) "Bergey`s Manual of Determinative Bacteriology", $8^{\text {th }}$ ed., Williams and Wilkins, Co. Baltimore, USA.

Bull, C. T., Weller, D. H. and Thomashow, L. S. (1991) Relationship between root colonization and suppression of Gaeumannomyces graminis tritici by Pseudomonas fluorescens strain 2-79. Phytopathol. 81,954.

Deans, S. G. and Ritchie, G. A. (1987) Antimicrobial properties of plant essential oils. International J. Food Microbiol. 5, 165-180.

Deans, S. G. and Sviboda, K. (1990) The antimicrobial properties of majoram (Origanum majorana L.) volitle oil. Flavour and Fragrance J. 5(3),187-190.

Fahy, P.C. and Persley, G. J. (1983) "Plant Bacterial Diseases: A Diagnostic Guide", Academic Press. Sydney, New York, London.

Egypt. J. Microbiol. 43 (2008) 
Guynot, M. E., Ramos, A. J., Seto, L., Purroy, P., Sanchis, V. and Marin, S. (2003) Antifungal activity of volatile compounds generated by essential oils against fungi commonly causing deterioration of bakery products. J. Appl. Microbiol. 94(5),893.

Hammer, K. A., Carson, C. F. and Riley, T.V. (1999) Antimicrobial activity of essential oils and other plant extracts, J. Appl. Microbiol. 86, 985-990.

Hayashida, S., Choi, M. Y., Nanri, N. and Miyaguchi, M.(1988) Production of potato common scab-antagonistic biofertilizer from swine feces with Streptomyces albidoflavus. Agric. Biol. Chem. 52, 2397-2402.

Helias, V., Andrivon, D. and Jouan, B. (2000) Development of symptoms caused by Erwinia carotovora spp. atroseptica under field conditions and their effects on the yield of individual potato plants. Plant Pathology, 49(1),23-32.

Ibrahim, S. S., El-Samahy, S. K., Abd-El-Fadeal, M. G., Awad, K. and Abd-ElHamid, A. A.(1987) The antimicrobial effect of some components of henna leaves (Lawsonia inermis). I. The antibacterial effect $2^{\text {nd }}$ Nat. Conf. of Pests and Dis. of Veg. and Fruits. Ismailia, Oct. 1987, pp.768-786.

Imai, H., Osawa, K., Yasuda, H., Hamashima, H., Arai, T. and Sasatsu, M. (2001) Inhibition by the essential oils of peppermint and spearmint of the growth of pathogenic bacteria. Microbios. 1, 31-39.

Johnson, I. F.,Curl, E. A., Bond, J. H. and Fibourg, H. A.(1960) Methods for Studying Soil Microflora. Burgess Publishing Co., p.15, Minneapolis, USA.

Kastelein, P., Schepel, E. G., Mulder, A., Turkensteen, L. J., Vuurde, J. W. and Van, L. (1999) Preliminary selection of antagonists of Erwinia carotovora subsp. atroseptica (Van Hall) dye for application during green crop lifting of seed potato tubers. Potato Research, 42(2), 161-171.

Kay, S. J. and Stewart, A. (1994) Evaluation of fungal antagonists for control of onion white rot in soil box trials. Plant Pathol. 43 (2),371-377.

Klopper, J. W. (1983) Effect of seed piece inoculation with plant growth-promoting rhizobacteria on populations of Erwinia carotovora on potato roots and in daughter tubers. Phytopathol. 73,217-219.

Kuster, E. (1972) Simple working key for classification and identification of named taxa included in the international Streptomyces project. Intern. Assoc. Microbiol. Soc. 22 , 139-148.

Lelliott, R. A. and Dickey, R. S. (1984) Genus VII. Erwinia, "Bergey`s Manual of Systematic Bacteriology", Williams \& Wilkins Company, Vol. 1,pp.469-476, Baltimore.

Liu, D., Anderson, N. A. and Kinkekl, L. L.(1995) Biological control of potato scab in the field with antagonistic Streptomyces scabies. Phytopathology, 85, 827-831.

Egypt. J. Microbiol. 43 (2008) 
Locci, R. (1989) Streptomyces and related Genera, "Bergey`s Manual of Systematic Bacteriology", Williams \& Wilkins Company, Vol. 4, pp. 2451-2508, Baltimore.

Lucon, C. M. M. and De Melo, I. S. (1999) Selection of antagonistic rhizobacteria to Erwinia carotovora subsp. atroseptica on potato tubers. Summa Phytopathological, 25(2), 132-136.

Lund, B. M. (1979)Bacterial soft rot of potatoes. In:"Plant Pathogens",Lovelock,p.19-49.

Nishimura, H., Okamota, S., Mayama, M., Ohtsuka, H., Nakajima, K., Tawara, K., Shinohira, M. and Shimaoka, N.(1961) Siomycin, a new thiostrepton-like antibiotic, J. antibiotics, Tokyo, Ser. A. 14, 255-263.

Nonomura, H. (1974) Key for classification and identification of 458 species of Streptomyces included in ISP. J. Ferment. Technol. 52(2), 78-92.

Phae, C. G., Shoda, M., Kita, N., Nokano, M. and Ushiyama, K. (1992) Biological control of crown and root rot and bacterial wilt of tomato by Bacillus subtilis NB22. Annals Phytopathol. Soc. Jap., 58(3), 329-339.

Roberti, R. and Selmi, C. (1999) Biological control of plant pathogens by Bacillus subtilis. Informatore Fitopatologica, 49(7/8), 15-21.

Ryan, A. D., Kinkekl, L. L. and Schottel, J. L.(2004) Effect of pathogen isolate, potato cultivar, and antagonist strain on potato scab severity and biological control. Biocontrol Science and Technology, 14( 3), 301-311.

Sharga, B.M. and Lyon, G. D.(1998) Bacillus subtilis BS 107 as an antagonist of potato blackleg and soft rot bacteria. Can. J. Microbiol. 44, 777-783.

Shirling, E. B. and Gottlieb, D. (1966) Methods for characterization of Streptomyces species, Intern. J. System. Bacteriol. 16 (3), 313-340.

Shirling, E. B. and Gottlieb, D. (1968) Cooperative description of type cultures of Streptomyces. II. Species description from first study. Intern. J. System. Bacteriol. 18(2), 69-189.

Singh, S. P., Negi, S., Chand, L. and Singh, A. K. (1992) Antimicrobial properties of essential oils from cgrysanthemum and Zingber leaves and rhizomes. Fitoterapia, 63(1), 73-75.

Staneck, J. L. and Roberts, G. D. (1974) Simplified approach to identification of aerobic actinomycetes by thin-layer chromatography. Applied Microbiology, 31,702-706.

Tawfik, A. E., Hanna, A. I., El-Ghareeb, L. A., Gomah, A. A. and Mahmoud, S. M. (2001) Applied approach for controlling brown rot and soft rot bacteria of potatoes. $J$. Agric. Sci. Mansoura Univ. 26(6), 3631-3642. 
Tolba, A. F.(1998) Biological control of some potato bacterial diseases, Ph.D. Thesis, Fac. Agric., Minufiya Univ., Egypt.

Tu, J. C.(1988) Antibiosis of Streptomyces griseus against Colletotrichum lindamuthianum. J. Phytopathol. 121,97-102.

Tukey, J. W. (1953) Some selected quick and easy methods of statistical analysis. Acad. Sci. 16(2),88-97.

Zedan, A. M. (1993) Antifungal properties of certain plant extracts with special reference to the possibility of controlling onion white rot disease using Eucalyptus robusta leaves. Egypt. J. Appl. Sci. 8 (12), 574.

(Received 16/5/2007; accepted $18 / 2 / 2008)$ 


\title{
مكافحة مرض العفن الطري في البطاطس باستخدام بكتريا

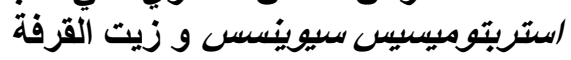

\author{
فتحي عواد منصور ، عطية حامد محمدين، عادل الصادق إسماعيل'و هدى

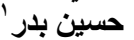 \\ قسم النباتـ كلية العلوم- جامعة المنصورة- المنصورة و 'معهد بحوث أمراض

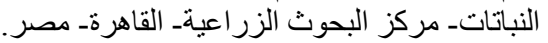

\begin{abstract}
مرض العفن الطري هو أحد أهم الأمراض البكتيرية التي تصيب محصول

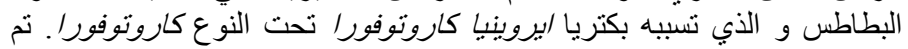

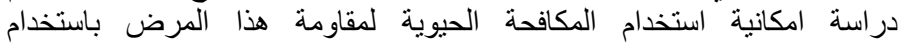

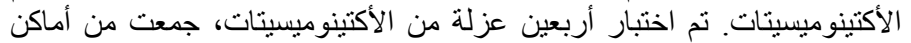

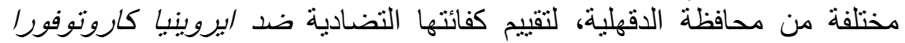

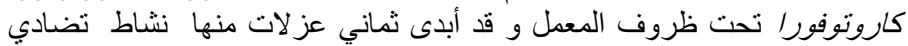

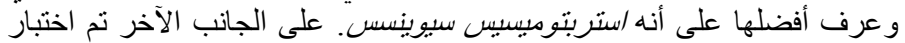

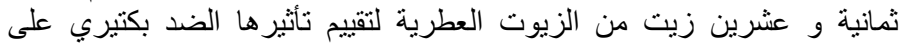

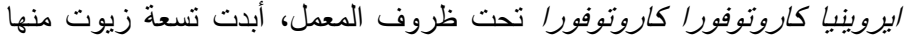

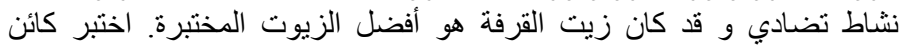

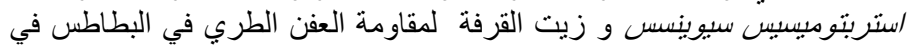

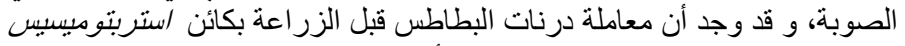

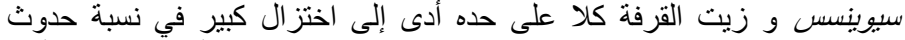

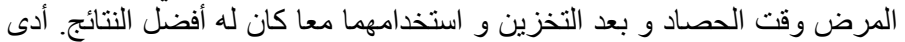

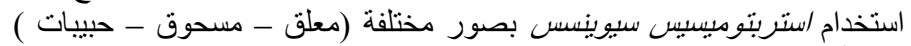

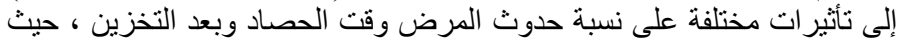

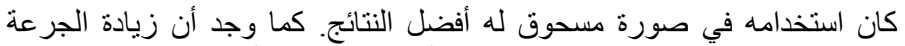

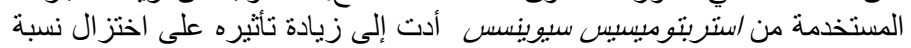

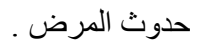

